\title{
Differences of Problem Solving Skill of The Fifth Grade Primary School Student: A Gender
}

\section{Analysis}

\author{
Algiyan Eko Prasetya \\ Departement of Master's Primay \\ Teacher Education \\ Sebelas Maret University, Surakarta, \\ Indonesia \\ algiyanekoprasetya@gmail.com
}

\author{
St. Y. Slamet \\ Departement of Primay Teacher \\ Education \\ Sebelas Maret University, Surakarta, \\ Indonesia \\ slametsty@yahoo.co.id
}

\author{
Budi Usodo \\ Departement of Mathematics \\ Teacher Education \\ Sebelas Maret University, Surakarta, \\ Indonesia \\ Budi_usodo@yahoo.com
}

\begin{abstract}
Ability to solve problem is very beneficial for people in their life. Each student can solve a problem that encountered in its own way, is one of the goals of mathematics teaching in primary schools. This study aimed to describe the difference between the mathematical problem solving ability of students male and female. The study was conducted in five classes at six elementary schools in Kebumen. The method in this research is done by giving the instrument a matter of solving the three boys and three girls aged 11-12 years. Drafting instruments based problem solving ability Polya theory. Instruments interviews were also given to the participants to determine the ways of solving the problems of each. Menunnjukkan research findings that there are differences in the stage of planning, the stage of implementing the plan and the stage looked back boys and girls. While there is no segnifikan differences between boys and girls at the stage of understanding the problem.
\end{abstract}

Keywords__ solving a math problem, gender, elementary school

\section{INTRODUCTION}

Mathematics education present at every level of education. Primary, secondary, and some in higher education. Mathematics education in schools generally aims to aid and develop human ability or skill to solve everyday problems [1], So that mathematics has a very strategic role for the progress of human civilization. But for some people, the math is not be considered easy [2].

Problems begin to appear when the student cannot answer questions from the teacher. And mathematics is often the cause of students considered stupid [3]. Problem-solving skills students become a major issue in most countries [4].

Program for International Student Assessment stated that mathematical skills of students and Indonesia ranked 63 out of 72 countries surveyed in 2015 [5]. This meant that students in Indonesia actually own abilities in mathematics, but cannot be categorized excellent. Other findings in the same year by TIMSS (Trends in International Mathematics and Science Study) states that the fourth grade primary school students in Indonesia was in the position of 45 out of 50 participants in the field of mathematics. The focus of problem solving ability becomes serious in learning mathematics. Problem solving ability of students who are not good will affect their lives.

Problem-solving ability is a complex cognitive activity [6]. Some describe the mathematical literacy matemartika problem solving as a series of mental operations carried out by someone to achieve specific goals [7].

Solving ability is the ability of individuals and visible in a person as a basic form of human skills [8]. Problem-solving skills to help someone to do life independently, solve the problems he encountered. Reference [9] in the life of the individual in society to resolve the problem, as well as students in the school. Solving problems related to student learning of mathematics [10], Social studies and science. Learning mathematics is closely linked with the same perception problem solving abilities [11].

Enterprises mathematical problem solving can be done after the troubleshooter to know in advance the necessary knowledge. Solving ability is very important to be trained and developed early [12]. Elementary school students are very easy to absorb knowledge so that knowledge that necessary to fulfilled maths problem can be taken early [13].

Polya problem solving method successfully performed at the basic education level, intermediate and advanced education. There are four steps in problem solving Polya [14].

Understand the Problems, to understand is an activitiy that must be done before the problem-solving activities. As suggested by John Dewey, the first step to solve the problem is to seek information on the matter. This means that by looking for information on various aspects, a step to understand the problem to be solved is made. There are different ways to understand the problem, namely: 1) identification of variables related to the problem; 2) the relationship between the variables that have been determined and 3) the variables needed through study or answers [15]. 
Devise a Plan, after identify the problem, the next step is to make referrals to plan appropriate strategies to solve problems. Understanding of problems produces various aspects required to determine the troubleshooting plan. In conducting any activity, which involves planning strategies, approaches and appropriate methods to solve a problem must be done in order to guarantee its implementation will be successful. There are several aspects that must be prepared to make a plan to solve a problem, namely: 1) choose the stages in accordance with the information obtained regarding the problem to be solved; 2) create an appropriate diagram, and this may help determine the appropriate steps to solve the problem; 3 ) make an analogy, in an attempt to determine the strategies, approaches and methods appropriate to draw an analogy with relatively similar problems, due to the different problems require different approaches and not any strategies, approaches and methods can be used to solve all problems [16].

Carry Out the Problem, understand a problem, and then make a good plan to solve the problem would be useless if it is not implemented. Attempts to show that problem solving is appropriate to solve the problem is to apply appropriate problem-solving approaches, strategies and models selected [17].

Look Back, anything sometimes made by humans is sometimes planned, sometimes not. It also occurs in implementing the plan. Efforts must be made to solve problems for reviewing the answers obtained. The activity can be done by using an answer by the inverse method, so it can be seen whether the answer is really as expected of problems, for example. For issues dealing with multiplication, can be done by looking back through the distribution phase [18].

Another issue stating there are gender differences in mathematical cognitive terms [19]. The obvious physical differences that are not visible indistinguishable. Differences in terms of cognitive allow one party to feel superior to others. This is of course an issue that is very interesting if studied further.

When it started to become an issue of gender difference the study, there are some researchers yangmencoba measure degan mathematical problem-solving abilities of different variables. Reference [20] analyzing the perception of the level of maslaah solving skills in primary schools. He found a correlation between the scores of perception problem solving skills with a willingness to do something and commitment through problemsolving abilities. Reference Felson [21] analyze differences in mathematical ability sexes. She found that female get better warning on math tests than male student.

The purpose of this study is to describe the differences in the level of mathematical problem solving ability in terms of gender. Therefore, the research question is "Is there any difference in the level of problem-solving ability of male and female student?".

\section{Material AND Method}

This type of research is descriptive research using a qualitative approach [22]. This study is not intended to disparage of one party or group of research subjects. The main objective of the study was to examine an idea of the level of students' problem solving abilities between male and female.

\section{A. Participants}

Subjects were 6 grade of five elementary school students between the ages of 10-12 years. The subject of the research was taken from the 6 public schools in Kebumen. The elementary school are SDN Kuwarasan, SDN 1 Gombong, SDN 1 Sidomukti, SDN 2 Jogomertan, SDN 2 Adimulyo and SDN 4 Karanganyar. There are 3 male and 3 female students from six different elementary schools. Selection of the subject of research by the acquisition of the maximum value of mathematics in the mid-term test at each school. The sixth participants are in the first rank in the class. The ability of all participants are in the same relative level.

\section{B. Data Collecting Tool and Analysis Techniques}

Data collection technique in accordance with the objectives of this research. Knowing differences problem-solving skill was using the data collection technique was developed, is used to synthesize the data students' problem-solving abilities of male and female. As a rule of researchers, used Polya approach that has been developed into a number of indicators. Math problems are given beforehand on the matter "distance and speed" is used to determine the student-solving abilities of men and women. Questions diberkan to students male and female alike and has been validated by experts. Further interviews to boys and girls to know how to solve a math problem on the matter "distance and speed". Notes field is also used to document the new findings in the field.

Ensure the validity of the data performed during the study. Triangulation techniques are used to obtained data that is completely valid and reliable. As a reference of the validity of the data is the result of tests, interviews and field notes [23].

Analyzes were performed after the data obtained [24]. Analysis of data using an interactive model of Miles and Huberman. Step of interactive model data analysis first is to collect data, as much as possible on the ground, reducing the data, findings the collected data and focused on things that are important. Presentation of data, make a brief description is used to clarify what actually happened. Draw conclusions, is the last to determine steps of conclusions from the research results.

\section{RESULT}

This section contains result from the study. Table 1 displays the description of the students' answers of male students and female students of the test problem solving abilities. 
TABLE 1 .

\begin{tabular}{|c|c|c|c|}
\hline \multirow{2}{*}{$\begin{array}{c}\text { Problem } \\
\text { Solving Step }\end{array}$} & \multirow{2}{*}{$\begin{array}{c}\text { Number } \\
\text { of test }\end{array}$} & \multicolumn{2}{|c|}{ Gender } \\
\hline & & Boy & Girl \\
\hline \multirow{2}{*}{$\begin{array}{l}\text { Understand the } \\
\text { problem }\end{array}$} & 1 & Understood & Understood \\
\hline & 2 & Understood & Understood \\
\hline \multirow[t]{2}{*}{ Devise a plan } & 1 & $\begin{array}{l}\text { Two good } \\
\text { plan One } \\
\text { good plan }\end{array}$ & All good plan \\
\hline & 2 & $\begin{array}{l}\text { All good } \\
\text { plan }\end{array}$ & All good plan \\
\hline \multirow{2}{*}{$\begin{array}{c}\text { Carry out the } \\
\text { problem }\end{array}$} & 1 & $\begin{array}{l}\text { Two on 2nd } \\
\text { level One on } \\
1 \text { st level }\end{array}$ & $\begin{array}{l}\text { Two on } 3 \text { th level } \\
\text { One on } 2 \text { nd level }\end{array}$ \\
\hline & 2 & $\begin{array}{l}\text { One on 3th } \\
\text { level Two on } \\
\text { 2nd level }\end{array}$ & $\begin{array}{l}\text { Two on } 3 \text { th level } \\
\text { One on } 2 \text { nd level }\end{array}$ \\
\hline \multirow{2}{*}{ Look back } & 1 & $\begin{array}{l}\text { Two check it } \\
\text { out } \\
\text { One not check } \\
\text { it out }\end{array}$ & All check it out \\
\hline & 2 & $\begin{array}{l}\text { Two check it } \\
\text { out } \\
\text { One not check } \\
\text { it out }\end{array}$ & All check it out \\
\hline
\end{tabular}

Another finding is the result of interviews with male students and female students about troubleshooting steps. Transcripts of some of the participants will be shown with the participant's name that has been camouflaged. Male participants is Jono, Tono, Joko and female participants is Ani, Santi, and Yani.

Results interview with Jono.

Researcher : What are you already familiar with the issue number 1 ?

Jono : : Already Sir.

Researcher : What do you know of Question 1?

Jono : motorcycle speed is $40 \mathrm{~km} / \mathrm{h}$, Distance A to B is $200 \mathrm{~km}$.

Researcher : What should be counted Jon?

Jono : : The time it takes from city A to city B, sir.

Researcher : How do you calculate it?

Jono : Using the formula distance divided by velocity.

Researcher : Did you check your answers when you're done?

Jono : I checked back.

Results interview with Santi.

Researcher : What are you already familiar with the issue number 1 ?

Santi : Yes Sir.

Researcher : What do you know of Question 1 ?

Santi : What I know is the speed of the motorcycle is $40 \mathrm{~km} / \mathrm{h}$, Distance A to B is $200 \mathrm{~km} \mathrm{Sir}$.

Researcher : What should be counted?

Santi : The time required for a distance of $200 \mathrm{~km}$, Sir.

Researcher : How do you calculate it?

Santi : Using the formula distance divided by velocity.

Researcher : Did you check your answers when you're done?
Santi : I checked back.

Results interview with Joko.

Researcher : Did you understand the question number 2?

Joko : Yes Sir.

Researcher : What do you know of about number 2?

Joko : first, speed $20 \mathrm{~km} \mathrm{/} \mathrm{h} \mathrm{for} 5$ minutes, then increase speed to $50 \mathrm{~km} / \mathrm{h}$ for 20 minutes and slow down the speed to $30 \mathrm{~km} / \mathrm{h}$ for 1 hour.

Researcher : What should be counted? Joko : The distance, Sir.

Researcher : How do you calculate it?

Joko : I feel confused pack. I added all the time and calculate average speeds. Then multiplying time and speed.

Researcher : Did you check your answers when you're done?

Joko : I have not had time to check again Sir.

Results interview with Ani.

Researcher : Did you understand the question number 2 ?

Ani : I understand Sir.

Researcher : What do you know of about number 2?

Ani : First, speed $20 \mathrm{~km} / \mathrm{h}$ for 5 minutes, then increase speed to $50 \mathrm{~km} / \mathrm{h}$ for 20 minutes and slow down the speed to $30 \mathrm{~km} / \mathrm{h}$ for 1 hour.

Researcher : What should be counted Ani?

Ani : The distance you have traveled.

Researcher : How do you calculate it?

Ani : First calculate the distance for 5 minutes at a speed of $20 \mathrm{~km} / \mathrm{h}$, the second to calculate the distance for 20 minutes at a speed of $50 \mathrm{~km} / \mathrm{h}$, and the last to calculate the distance for 1 hour with speed $30 \mathrm{~km} / \mathrm{h}$. Then add up all the known distance.

Researcher : Did you check your answers when you're done?

Ani : Already I checked, Sir.

Results of a small note stating that the three pertisipant of female students are equal to the work on tests and interviews. But unlike the male participants there was one student who did not do the problems properly and do not double check the answer. This is due to the unhealthy one student. One of the male participants had been ill (influenza). Might cause maximal one male participant in solving mathematical problems is pain experienced.

Validity and reliability of data from a group of men made by comparing the results of the interview participants were male with the results of the test group of men and little notes from investigators. Data from a group of men declared valid and reliable. As well as the validity and reliability of the data groups of women. Data from female's groups declared valid and reliable.

\section{Discussion AND CONCLUSION}

Gender differences become an interesting issue discussed. There are many variables that can be studied from each side, 
one of which is the level of mathematical problem solving. Research on differences in male and female in terms of mathematical problem solving a lot of attention of researchers.

Some studies say that the mathematical abilities of male better than female [25]. Differences math skills can be seen in terms of affective and psychomotor, but it will be clearer if viewed in terms of the cognitive. Signifikan differences in male and female were also seen in the ability of solving mathematical [26].

From table 1 visible difference in the problem-solving ability groups and groups of men. Problem-solving abilities of a group of men and women for each different matter. Next will be presented analytical problem solving skills for boys and girls.

\section{A. Understanding the Problem}

In order to question number 1 and number 2, groups of men and women there is no difference. It shows that boys and girls do not differ in understanding the problem. Analysis of the results of the interview stated that participants were men and women understand the issues. Problem "distance and speed" which can be understood properly tested. by the participants.

\section{B. Devise a plan}

Question number 1, two male students to plan well while the other one does not plan a good problem-solving. As for the three women students are already planning with good problem solving. Problem No. 2, seen all the boys and girls are already planning well. Similarly, analysis of test results, analysis of interviews with participants also expressed the same thing. Both male participants can plan with good problem-solving and one male participant can not plan properly. As with the women, all participants can plan the resolution of issues properly and systematically.

\section{Carry Out the Problem}

At this stage of implementing the planned significant changes. To Question 1, two male students carrying out a plan to level 2 , and the other one only get level 1 . This is in contrast with female students who get 2 students with level 3 and one on level 2. To work Question 2 group men increased by one student is at level 3 and the other two at level 2. While women's groups have not improved but is still above the group of men. These differences are also seen at the time of the interview session that express the degree of implementation of the plan that has been prepared by the three male participants can only be categorized as moderate. While the female participants to carry out planning problem solving with high category.

\section{Look Back}

To stage re-examine the work completed. This group of women are all checking back job. Sedangkah to a men's group only two students who check the answer and the other one does not check the answer. This illustrates that students permpuan advantage over boys in terms of persistence check answers. Honesty may be checked by in-depth interviews with participants on stage to re-examine the steps and problem solving. One of the participants were male-lai admitted that has not had time to check back the answer.

Different things seen at the conclusion of this study. Differences in the level of mathematical problem solving boys no better than female students in terms of the settlement plan, Implemen plan, and the thoroughness and diligence check answers. However, there is no equality in terms of the level of solving problem and understand the problems. (A) Male and female students can understand problem they met very well. There is no clear distinction between the two. Differences in the level of mathematical problem solving in students male and permempuan began to look in step (b) planning problem resolution. Girls walkin worse than boys in the settlement plan. Planning students of female is more sistematic and logical than male students. (C) Implementation plan of solving the problem "distance and speed" of female students is much better than the male one. This is because in the planning stages of female students problem solving are arranged clearly and systematically. As with the implementation of the plan of solving the problem of men who were poor and even the problem is not resolved. (C) The accuracy and persistence can be shown on the stage of checking back answers. All the participants women recheck the answer while the male participants are not all check answer.

Results of research conducted wherewith inidan previous study conclusions are berbedaan. It states that the uncertain of males are better than females in math problem-solving skills. The results of studies that support the results of this study are Felson (1991) which states that the female student mathematics test results better than the male. There is gender equality in cognitive terms, as long as each party can maximize their potential [27].

\section{REFERENCES}

[1] Wilson, W. Elementary school mathematics priorities. Articles on Best Practice, 6, 1-10. (2009). Retrieved from https://www.aasa.org/uploadedFiles/Publications/Journals/AASA_Journ al_of_Scholarship_and_Practice/JSP-Spring_09vFINAL 92209.pdf\#page $=39$.

[2] Wu, H. H. Understanding Numbers in Elementary School Mathematics. Books.Google.Com, 1-27. (2011). Retrieved from http://books.google.com/books?hl=en\&lr=\&id=_BZPaeWB7YYC\&oi=f nd\&pg=PR15\&dq=\%22negative+numbers $\% 22+$ understanding\&ots $=\mathrm{Zfr}$ _el2prh\&sig=Qi3pEdWv0vVyMDfb07jf8eNJhvs\%5Cnpapers://5587b4e 2-af07-460c-b041-e9e68a9c0f25/Paper/p17671

[3] Karigi, M. W., Tumuti, S., Karigi, M. W., \& Tumuti, S. (n.d.). in Selected Public Secondary Schools in Kiambaa Division of Central Province, Kenya.

[4] Tambychik, T., \& Meerah, T. S. M. Students' difficulties in mathematics problem-solving: What do they say? In Procedia - Social and Behavioral Sciences (Vol. 8, pp. 142-151). (2010). https://doi.org/10.1016/j.sbspro.2010.12.020

[5] PISA. PISA 2015 Results in Focus. OECD. (2016).https://doi.org/10.1787/9789264266490-en

[6] Zhu, Z. Gender differences in mathematical problem solving patterns: A review of literature. International Education Journal, 8(2), 187-203. (2007).

[7] Szetala, W., \& Nicol, C. Evaluating Problem Solving in Mathematics. Educational Leadership. (1992). 
[8] Bassok, M., \& Novick, L. R. Problem Solving. In The Oxford Handbook of Thinking and Reasoning.

(2012).https://doi.org/10.1093/oxfordhb/9780199734689.013.0021.

[9] Tao, T., \& Watkins, J. J. Solving mathematical problems: a personal perspective. The Mathematical Intelligencer (Vol. 29).

(2007).https://doi.org/10.1007/BF02985692

[10] Pehkonen, E. Problem solving in mathematics education in Finland. Proceedings of ICMI Symposium, (Ncsm), 7-11. (2008). https://doi.org/10.1007/ 978-94-007-4978-8

[11] Eisenmann, P. PROBLEM SOLVING IN SCHOOL MATHEMATICS BASED ON. Problem Solving School Mathematics Based On Heuristic Strategies, 7(1), 1-6. (2012).https://doi.org/10.7160/eriesj.2013.070101.Introduction

[12] Rai, H. M., Khan, S., Chauhan, Y., \& Chauhan, S. Issues on Problem Solving in Mathematics. International Journal of Research (IJR), 1(10), 1705. (2014)

[13] Vermeer, H. J., Boekaerts, M., \& Seegers, G. Motivational and gender differences: Sixth-grade students' mathematical problem-solving behavior. Journal of Educational Psychology, 92(3), 308-315. (2000).https://doi.org/10.1037//0022-0663.92

[14] Polya, G. Polya 's Problem Solving Techniques. In How To Solve It.(1945). (pp. 1-4).

[15] Smith, S. Problem solving in mathematics. Early Years, 6(2), 15-24. (1986).https://doi.org/10.1080/0957514860060203

[16] Schoenfeld, A. H. Polya, Problem Solving, and Education. Source: Mathematics Magazine, 60(5), 283-291. (1987).https://doi.org/10.2307/2690409

[17] Tripathi, P. Problem Solving in Mathematics: A tool for Cognitive Development. Proceedings of epiSTEME 3, 168-173. (2009). Retrieved from http://web.gnowledge.org/episteme3/pro_pdfs/27-tripathi.pdf

[18] Shirali, S. A. George Pólya \& problem solving. An appreciation. Resonance, 19(4), 310-322. (2014). https://doi.org/10.1007/s12045-0140037-7

[19] Arnup, J. L., Murrihy, C., Roodenburg, J., \& McLean, L. A. Cognitive style and gender differences in children's mathematics achievement. Educational Studies, 39(3), 355-368. (2013). https://doi.org/10.1080/03055698.2013.767184

[20] Yavuz, G., Deringöl, Y., \& Arslan, Ç. Elementary School Students Perception Levels of Problem Solving Skills, 5(11), 1896-1901. (2017).https://doi.org/10.13189/ujer.2017.051106

[21] Felson, R. B., \& Trudeau, L. Gender Differences in Mathematics Performance. Social Psychology Quarterly, 54(2), 113. (1991). https://doi.org/10.2307/2786930

[22] Baškarada, S. Qualitative Case Study Guidelines. Qualitative Report, 19(40), 1-25. (2014). https://doi.org/10.7748/nr2013.05.20.5.28.e327

[23] Brink, H. I. L. Validity and reliability in qualitative research. Curationis, 16(2), 35-38. (1993). https://doi.org/10.4102/curationis.v16i2.1396

[24] Miles, M., Huberman, M., \& Saldana, J. Qualitative Data Analysis. European Journal of Science Education (Vol.1). (2014).https://doi.org/10.1080/0140528790010406

[25] Devine, A., Fawcett, K., Szücs, D., \& Dowker, A. Gender differences in mathematics anxiety and the relation to mathematics performance while controlling for test anxiety. Behavioral and Brain Functions, 8(1), 33. (2012).https://doi.org/10.1186/1744-9081-8-33

[26] Rosli, R., Goldsby, D., \& Capraro, M. M. Assessing students' mathematical problem-solving and problem-posing skills. Asian Social Science, 9(16 SPL), 54-60. (2013). https://doi.org/10.5539/ass.v9n16p54

[27] Duffy, J., Gunther, G., \& Walters, L. Gender and Mathematical Problem Solving. Sex Roles, 37(7/8), 477-494. (1997).https://doi.org/http://dx.doi.org/10.1023/A:1025602818005 